\title{
EVSItalia Database of Mires and Wetlands of Italy
}

\author{
Laura Casella, Francesco Spada \& Emiliano Agrillo
}

\begin{abstract}
A database of vegetation plots of mires \& wetlands of Italy is presented (EVSItalia Database of Mires and Wetlands of Italy, GIVD ID EU-IT-016). The database currently stores 263 georeferenced relevés from published certified phytosociological sources and from personal archives. But it is rapidly growing. Currently the data are mostly from the geographic range of the peninsular Italy (personal data), where relic mires are recorded. For the Alpine region, data are derived from literature sources. All the vegetation types recorded along the hydrological gradient are included: submerged and floating plants (macrophytes), emergent helophytes stands, swamps, etc. The aim is to provide data for a review of the classification of Italian wetlands, and namely mires, and its parameterisation by the means of the geostatistical analysis. This is done mostly to provide reasonably valid data for plans and programs on the conservation of mires and related ecosystems and to facilitate the exchange of information about mires. All the relevés are uploaded to TURBOVEG. An ArcGis Database stores information about localization: Operational Geographic Units (OGU), corresponding to the quadrates of the Italian floristic grid, precise GPS or toponym information as well as descriptive records of locations extracted from geographical information systems are also stored.
\end{abstract}

Keywords: Italian vegetation database; mire; wetland; TURBOVEG.

GIVD Database ID: EU-IT-016

Last update: 2012-06-21

\section{EVSItalia Database Mires \& Wetlands of Italy}

Scope: The data-set aims to store information from published/certified phytosociological sources in order to support ongoing reviews based on larger data-sets for comparative classification of Italian vegetation types.

Status: ongoing capture

Period: $1967-2003$

Database manager(s): Laura Casella (laura.casella@isprambiente.it); Emiliano Agrillo (emiliano.agrillo@uniroma1.it)

Owner: [NA]

Web address: [NA]

Availability: according to a specific agreement

Online upload: no Online search: no

Database format(s): TURBOVEG, Excel, ArcGis database Export format(s): TURBOVEG, Excel, ArcGis database

Publication: [NA]

Plot type(s): normal plots

Non-overlapping plots: 107

Plot-size range: $1-200 \mathrm{~m}^{2}$

Total plot observations: 107

Estimate of existing plots: [NA]

Number of sources: 29
Completeness: [NA]

Valid taxa: [NA]

Countries: IT: $100.0 \%$

Forest: [NA] — Non-forest: [NA]

Guilds: all vascular plants: $100 \%$; bryophytes (terricolous or aquatic): $80 \%$; algae (terricolous or aquatic): $80 \%$

Environmental data: [NA]

Performance measure(s): [NA]

Geographic localisation: [NA]

Sampling periods: [NA]

Information as of 2012-07-26; further details and future updates available from http://www.givd.info/ID/EU-IT-016

Laura Casella (laura.casella@isprambiente.it)

ISPRA - National Institute for Environmental Protection and Research, Rome, ITALY

Francesco Spada (francesco.spada@uniroma1.it), Emiliano Agrillo*(emiliano.agrillo@uniroma1.it)

Department of Environmental Biology, Sapienza University of Roma, Rome, ITALY

*Corresponding author 